\title{
PCR in situ hybridisation detection of HPV 16 in fixed CaSki and fixed SiHa cell lines
}

\author{
J J O'Leary, G Browne, M I Johnson, R J Landers, M Crowley, I Healy, J T Street, \\ A M Pollock, F A Lewis, A Andrew, C Cullinane, O Mohamdee, W F Kealy, J Hogan, \\ C T Doyle
}

Nuffield Department of Pathology and Bacteriology,

University of Oxford

J J O'Leary

Academic Unit of

Pathological Sciences, University of Leeds

G Browne

M I Johnson

F A Lewis

A Andrew

O Mohamdee

Department of

Pathology, University

College, Cork, Ireland

R J Landers

$M$ Crowley

I Healy

J T Street

A M Pollock

W F Kealy

J Hogan

C T Doyle

Department of

Pathology, St James'

Hospital, Leeds

C Cullinane

Correspondence to:

Dr J J O'Leary, Nuffield

Department of Pathology

and Bacteriology, University

of Oxford, John Radcliffe

of Oxford, John Radcliffe

Oxford OX3 9DU

Accepted for publication

19 April 1994

\begin{abstract}
Aims-To investigate the feasibility of using fixed cells with the polymerase chain reaction (PCR) in situ hybridisation and to investigate possible reasons for reaction failure.
\end{abstract}

Methods-Fixed SiHa and CaSki cells were used in an experimental model of PCR in situ hybridisation for the detection of low and intermediate copy number viral infection in fixed cells.

Results-PCR in situ hybridisation was able to detect one to two copies of human papillomavirus (HPV) 16 in SiHa cells, using small fragment amplicons (120 base pairs), confirming the high detection sensitivity and flexibility of the technique. Problems were encountered with localisation of PCR amplified product in CaSki cells (200-300 copies of HPV 16 per cell) owing to diffusion of product post amplification. Overall, $40 \%$ of reactions were successful, which confirms the current unreliability of the technique. Within cell preparations, about $50 \%$ of cells contained amplified product.

Conclusion-PCR in situ hybridisation represents the marriage of two revolutionary molecular pathological techniques. However, it is currently unreliable, with reaction failure common. Standardised, dedicated equipment is urgently required if the technique is to achieve universal acceptance. In the future, the technique may be used to detect chromosomal translocations in human tumours and to study cellular gene expression.

\section{(7 Clin Pathol 1994;47:933-938)}

The polymerase chain reaction (PCR) permits the selective in vitro amplification of a particular region of nucleic acid by mimicking the phenomena of in vivo DNA replication. ${ }^{1}$ PCR has been extensively used to amplify specific DNA sequences for use in the molecular analysis of many diseases, for which formalin fixed, paraffin wax embedded tissue has been used. However, one limitation for the histopathologist was that it was impossible to localise amplified DNA sequences in cells or tissue sections. Recently, several studies have described a new technique which combines PCR with in situ hybridisation, permitting the localisation of specific amplified DNA signals within isolated cells and tissue sections. This technique has been variously known as in situ PCR or PCR in situ hybridisation. ${ }^{2}$

In situ PCR refers to use of a biotin or digoxigenin labelled nucleotide directly in the PCR mix and subsequent detection of the labelled amplified product using standard in situ detection protocols. PCR in situ hybridisation occurs when PCR amplification of a tissue section or cell suspension is carried out, followed by application of a biotin or digoxigenin labelled probe to the amplified product and detection of the hybrid by standard in situ detection protocols. The technique was first described in 1990 by Haase et al, ${ }^{3}$ who amplified lentiviral DNA in infected cells and subsequently detected the amplified DNA using in situ hybridisation. Nuovo et al further modified and developed this technique for the identification of different types of human papillomavirus (HPV) in formalin fixed, paraffin wax embedded samples. ${ }^{45}$

Why should this technique work? Many people question the scientific basis of the in situ PCR process, with many centres reporting failure of the technique. Theoretically, fixed cells should act like sponges or at least semipermeable dialysis bags. It is reasonable, therefore, to assume that PCR reagents (Taq, primers, etc.) can diffuse through the cell membrane and into the cytosolic and nuclear components of the cell.

Preliminary results from Nuovo et al using the technique, suggested that most amplified product appeared to localise, although "leakage" did occur into the surrounding medium..$^{245}$ The technique can be conveniently performed on a normal conventional thermal cycling block, on specially designed thermal cyclers for slide PCR, or in a microprocessor controlled oven.

In this paper we examine PCR in situ hybridisation in relation to the detection of low and intermediate copy HPV infection in fixed $\mathrm{SiHa}$ and $\mathrm{CaSki}$ cell lines and address some of the fundamental technical problems encountered when using the technique for the identification of viral pathogens in histopathological material.

\section{Methods}

We evaluated the use of PCR in situ hybridisation with paraffin wax embedded cell lines for the detection of low and intermediate copy number HPV infection in virally infected $\mathrm{SiHa}$ and CaSki cells. HPV 16 was amplified using specific primers which amplify a 120 base pair fragment of HPV 16. Primers for 
Primer sequences used

\begin{tabular}{|c|c|c|}
\hline Primer & Sequence & Genome position \\
\hline \multicolumn{3}{|l|}{$H P V 6 B$} \\
\hline $\begin{array}{l}\text { Primer } 1 \\
\text { Primer } 2\end{array}$ & $\begin{array}{l}\text { CCTGTTTCGAGGCGGCTATCCATA } \\
\text { GTACAATTTAGCTTTATGAACCGCGCCTTGGTT }\end{array}$ & $\begin{array}{l}260-283 \\
464-496\end{array}$ \\
\hline HPV 16 & & \\
\hline $\begin{array}{c}\text { Primer } 1 \\
\text { Primer } 2 \\
H P V 18\end{array}$ & $\begin{array}{l}\text { TCAAAAGCCACTGTGTCCTG } \\
\text { CGTGTTCTTGATGATCTGCAA }\end{array}$ & $\begin{array}{l}421-440 \\
521-540\end{array}$ \\
\hline $\begin{array}{c}\text { Primer } 1 \\
\text { Primer } 2\end{array}$ & $\begin{array}{l}\text { AAACTAACTAACACTGGGTTATACA } \\
\text { ATGGCACTGGCCTCTATAGT }\end{array}$ & $\begin{array}{l}378-402 \\
502-521\end{array}$ \\
\hline $\begin{array}{l}\text { Primer } 1 \\
\text { Primer } 2\end{array}$ & $\begin{array}{l}\text { AACAGTTAAAAAACCTTTAAA } \\
\text { AGTTTCTCTACGTCGGGACCTC }\end{array}$ & $\begin{array}{l}378-398 \\
528-549\end{array}$ \\
\hline
\end{tabular}

Sequences obtained from EMBL database.
30 minutes, followed by xylene at room temperature for 10 minutes, and absolute alcohol at room temperature for a further 10 minutes. The slides were transferred to fresh absolute alcohol and rehydrated through a graded alcohol series to water over a 10 minute period. The prepared sections were immersed in $0.02 \mathrm{M} \mathrm{HCl}$ for 10 minutes, washed twice in PBS for five minutes each, and treated with $0.01 \%$ Triton X-100 in PBS for three minutes. After this, the sections were washed twice in PBS for five minutes each and then incubated in prewarmed proteinase $\mathrm{K}$ buffer (50 mM TRIS- $\mathrm{HCl}, \mathrm{pH} 7 \cdot 6,5 \mathrm{mM}$ EDTA) at $37^{\circ} \mathrm{C}$ for 10 minutes and then treated with proteinase $\mathrm{K}(0.1-0.5 \mathrm{mg} / \mathrm{ml})$ at $37^{\circ} \mathrm{C}$ for 10 to 20 minutes. The slides were washed in two changes of PBS containing $2 \mathrm{mg} / \mathrm{ml}$ of glycine for five minutes each, followed by immersion in aqueous $20 \%$ acetic acid at $4^{\circ} \mathrm{C}$ for $15 \mathrm{sec}-$ onds. The sections were then washed in two changes of PBS for 10 minutes each and postfixed in $4 \%$ paraformaldehyde in PBS for five minutes. Washing in PBS for five minutes was then performed, and the sections were dehydrated through graded alcohols.

For amplification of paraffin wax embedded cell lines, the slide containing the fixed cell suspension was placed in an aluminium foil boat, trimmed to slightly larger proportions than the slide. PCR solution $(20 \mu \mathrm{l})$ consisting of PCR buffer $(50 \mathrm{mM} \mathrm{KCl}, 10$ $\mathrm{mM}$ TRIS- $\mathrm{HCl}(\mathrm{pH} 8.3)$ at room temperature, $4.5 \mathrm{mM} \mathrm{MgCl}, 0.01 \%$ gelatin) and 200 $\mathrm{mM}$ each of dNTP and $5 \mu \mathrm{M}$ primers were placed on top of the cell suspension. The well was covered with a pre-cut piece of Gel Bond (FMC Bioproducts), hydrophobic side down. The slide (in the aluminium foil boat) was placed on the heating block of the thermal cycler and the temperature allowed to increase to $80^{\circ} \mathrm{C}$. Once the temperature had reached $80^{\circ} \mathrm{C}$, a corner of the gel bond was lifted and $2.5 \mu 1$ Taq DNA polymerase $(2.5$ units per $12.5 \mu \mathrm{l}$ final concentration) were added to the PCR mix contained on the slide. The coverslip (gel bond) was then replaced and the margins sealed with nail polish. Preheated mineral oil $(1-2 \mathrm{ml})\left(80^{\circ} \mathrm{C}\right)$ was placed on top of the slide to ensure optimal thermal kinetics. The following PCR protocol was applied: $94^{\circ} \mathrm{C}$ for six minutes, 40 cycles of $55^{\circ} \mathrm{C}$ for two minutes, and $94^{\circ} \mathrm{C}$ for one minute.

The temperatures given refer to the temperatures of the glass slide. This was checked using a thermocouple device. It is important that the initial denaturation temperature and cycling temperatures are achieved on the glass slide. After amplification the slide was dipped in chloroform to remove mineral oil and the gel bond coverslip carefully removed. Gel Bond, hydrophobic side towards the cell suspension, allows the PCR reagent mix to remain on the tissue in the well.

After amplification the slides were dipped carefully in $100 \%$ alcohol and dehydrated. Post fixation in $2 \%$ paraformaldehyde to maintain localisation of PCR product was also carried out.
Sections $(5 \mu \mathrm{m})$ were cut on to the "welled" slides and placed on a hot plate for 24 to 48 hours to achieve maximum section adhesion. Section dewaxing was carried out by immersing the slides in xylene at $37^{\circ} \mathrm{C}$, for 
Figure $1 \quad P C R$ in situ hybridisation of fixed $\mathrm{SiHa}$ cells showing two copies of HPV16 per cell nucleus using a biotin labelled probe.
$\mathrm{NaCl}, 50 \mathrm{mM} \mathrm{MgCl}_{2}$ ).

Development reagent (NBT/BCIP)-alkaline phosphate detection system. A fresh solution was made just before use and kept in the dark. This consisted of buffer $2(3.75 \mathrm{ml})$, nitroblue tetrazolium (NBT) $(16.5 \mu \mathrm{l})$, bromochloroindoyl phosphate (BCIP) $(12 \cdot 5 \mu \mathrm{l})$. TBS (TRIS-buffered saline) (50 mM TRIS$\mathrm{HCl}, 100 \mathrm{mM} \mathrm{NaCl}, \mathrm{pH} \mathrm{7 \cdot 2)}$.

TBT (blocking reagent) for the detection of digoxigenin labelled probes ( $50 \mathrm{mM}$ TRIS$\mathrm{HCl}, 100 \mathrm{mM} \mathrm{NaCl}(\mathrm{pH} \mathrm{7.2)}, 3 \%$ (w/v) bovine serum albumin (BSA) and $0.5 \%$ Triton X-100 (v/v)).

For the detection of biotinylated probes, ${ }^{7}$ the slides from the posthybridisation wash steps were transferred into buffer 1 containing $5 \%(\mathrm{w} / \mathrm{v}) \mathrm{BSA}$ and incubated at room temperature for a minimum of 30 minutes. Excess buffer was wiped from the slides and the slides transferred to a slide incubation tray. A few drops of buffer 1 containing Avidin DN (Vector) at a concentration of $10 \mu \mathrm{l} / \mathrm{ml}$ were added and the slides incubated at room temperature for 10 minutes. The slides were washed with agitation in two changes of buffer 1 for 10 minutes each. The slides were then

Biotinylated and digoxigenin labelled genomic HPV 16 probe contained in pBR322 (a gift from Dr Zur Hausen) was prepared using the nick translation labelling technique. The HPV 16 probe $(75 \mu \mathrm{l})(200 \mathrm{ng} / \mathrm{ml})$ in hybridisation buffer ( $50 \%$ dextran sulphate, $2 \times$ SSC, $0.2 \%$ dried milk powder, $50 \%$ formamide) was applied to the centre of the well of the PH106, C A Hendley glass slide (SSC $=$ sodium chloride and sodium citrate). For multiwell slides (PH005, C A Hendley), 8-10 $\mu \mathrm{l}$ of probe was applied to the centre of the well. Gel bond films were cut to coverslip size and placed hydrophobic side down, over each section. The gel bond was sealed in place with nail varnish.

Slides were placed onto a preheated baking tray and incubated at $90-95^{\circ} \mathrm{C}$ for $10 \mathrm{~min}-$ utes. Finally, the slides were transferred to a humidified box and incubated at $37-42^{\circ} \mathrm{C}$ overnight or at $42^{\circ} \mathrm{C}$ for two hours.

For posthybridisation washes, the gel bond coverslips were removed with a scalpel blade and the slides washed in SSC with agitation according to the following protocol:

(a) $2 \times$ SSC at room temperature for 10 minutes;

(b) $2 \times \mathrm{SSC}$ at $60^{\circ} \mathrm{C}$ for $20 \mathrm{~min}$;

(c) $0.2 \times \mathrm{SSC}$ at room temperature for 10 min;

(d) $0.2 \times \mathrm{SSC}$ at $42^{\circ} \mathrm{C}$ for two minutes;

(e) $0.1 \times$ SSC at room temperature for 10 min;

(f) $2 \times$ SSC at room temperature, for one to two minutes.

The following solutions were required for hybridisation detection protocols:

Buffer $1(0 \cdot 1 \mathrm{M}$ TRIS-HCl (pH 7.5), $0 \cdot 1 \mathrm{M}$ $\mathrm{NaCl}, 2 \mathrm{mM} \mathrm{MgCl}_{2}$, and $0.05 \%$ Triton-X100).

Buffer $2(0 \cdot 1 \mathrm{M}$ TRIS- $\mathrm{HCl}(\mathrm{pH} 9 \cdot 5), 0 \cdot 1 \mathrm{M}$

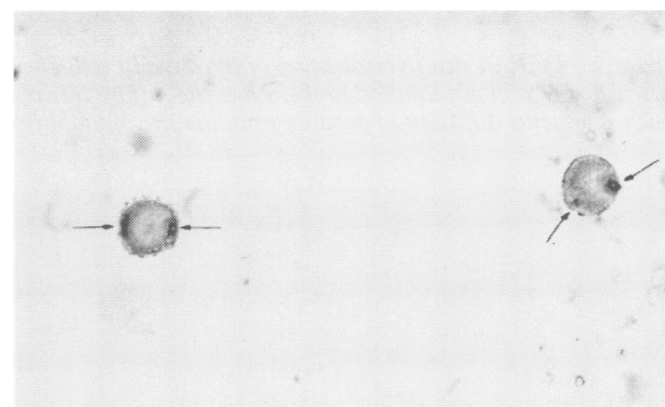

Figure 2A PCR in situ hybridisation of fixed SiHa cells showing two copies of HPV16 per cell nucleus in two adjacent SiHa cells, using a biotin labelled probe.

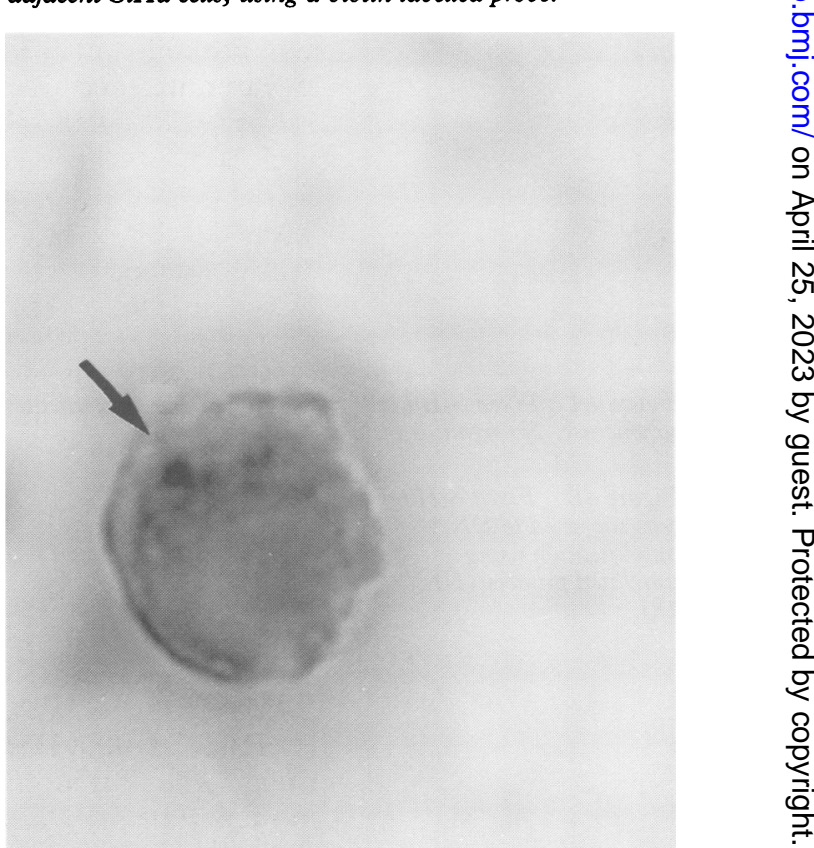

Figure 2B PCR in situ hybridisation of fixed SiHa cells showing one copy of HPV 16 per cell nucleus, using a digoxigenin labelled probe. 
Figure $3 P C R$ in situ hybridisation of fixed SiHa cells showing two copies of HPV16 per nucleus using a biotin labelled probe. Note the diffuse intranuclear signal at one locus, which represents diffusion of product from the site of amplification.

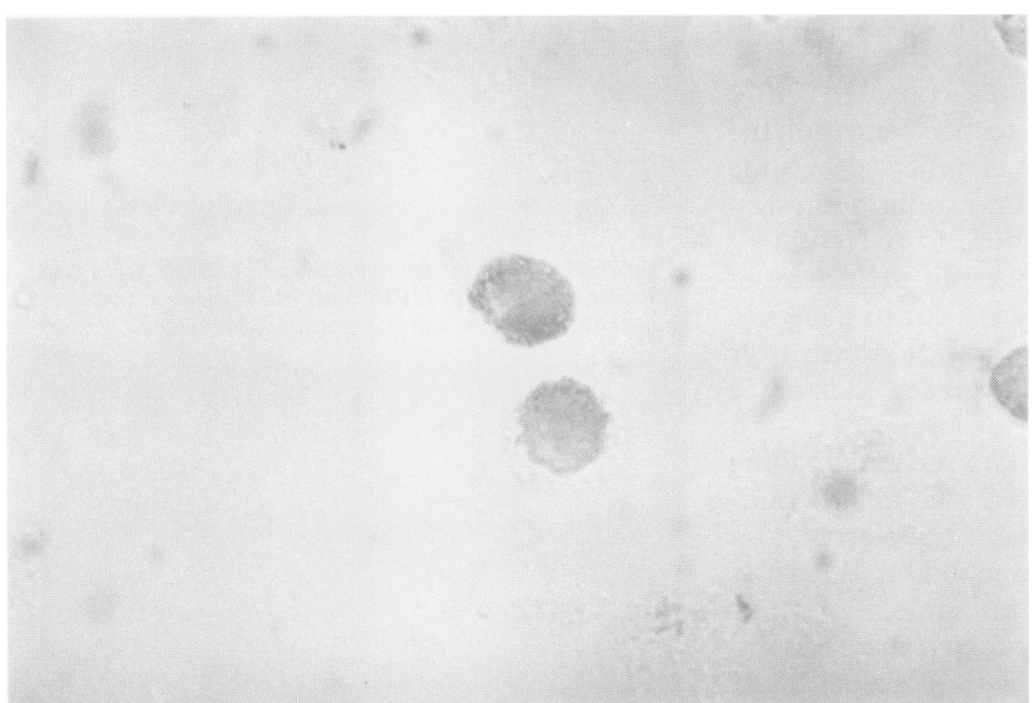

Figure $4 A$ Fixed SiHa cells subjected to DNA amplification protocol omitting Taq DNA polymerase. No signal is visible.

Figure 4B Fixed SiHa cells subjected to DNA amplification using unrelated primers (HPV 18). returned to the incubation tray and a few drops of buffer 1 containing biotinylated alkaline phosphatase (Vector) at a concentration of $10 \mu \mathrm{l} / \mathrm{ml}$ were added to each section. Incubation at room temperature for $10 \mathrm{~min}$ utes was carried out. The slides were washed with agitation twice in buffer 1 for 10 minutes each. Transfer of slides into buffer 2 then took place and they were allowed to equilibrate for 30 minutes. The slides were returned to the incubation tray and the sections were covered with NBT/BCIP development reagent. Colour development was monitored after five minutes and then continuously until development looked complete. The reaction was terminated by immersion of slides in PBS or distilled water for five minutes.

For detection of digoxigenin labelled probe ${ }^{8}$ the slides from the posthybridisation washes were immersed in TBT (blocking reagent) at $22^{\circ} \mathrm{C}$ for 10 minutes. The slides were transferred to a slide incubation tray and incubated in alkaline phosphatase conjugated antidigoxigenin (Boehringer, Germany) diluted in 1 in 600 in TBT. After this the slides were washed in TBS for five minutes, twice. Signal development using NBT/BCIP development reagent was carried out for 10-30 minutes. The colour development reaction was terminated by washing in distilled water for five minutes.

\section{Results}

Figures 1, 2A, 2B, and 3 show typical results obtained with the SiHa cell line using PCR in situ hybridisation. SiHa cells contain one to two copies of HPV 16 per nucleus and these cannot be routinely detected by non-isotopic in situ hybridisation (NISH) except for complex five-step detection procedures. ${ }^{9}$ The result is morphologically similar to that obtained by Herrington $e t a l^{9}$ using NISH and a five-step detection protocol for digoxigenin labelled genomic probes. When Taq DNA polymerase was omitted from the reaction protocol, amplification was not achieved (fig 4A). Unrelated primers also did not yield amplification (fig 4B).

In this study patchy amplification was seen, and reproducibility of results was not always achieved. On average, $50 \%$ of cells on most slides contained amplified product, with about $40 \%$ of PCR in situ hybridisation reac-

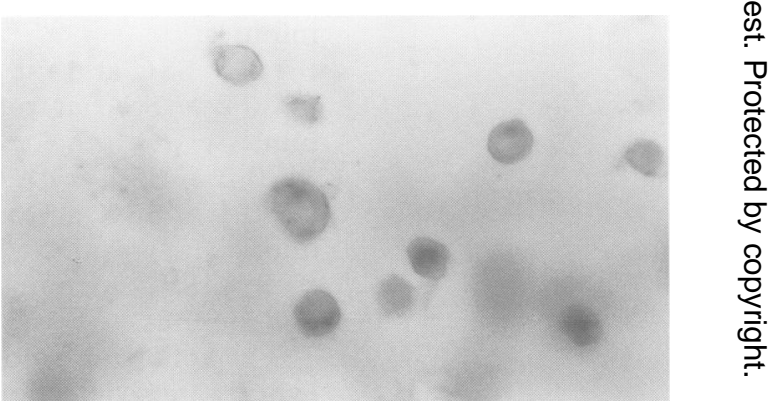

Figure $5 P C R$ in situ hybridisation of fixed SiHa cells showing diffuse staining, with occasional cells showing dot positivity. Sometimes, interpretation of diffuse staining may be difficult and may simply reflect background staining due to detection reagents, etc. 


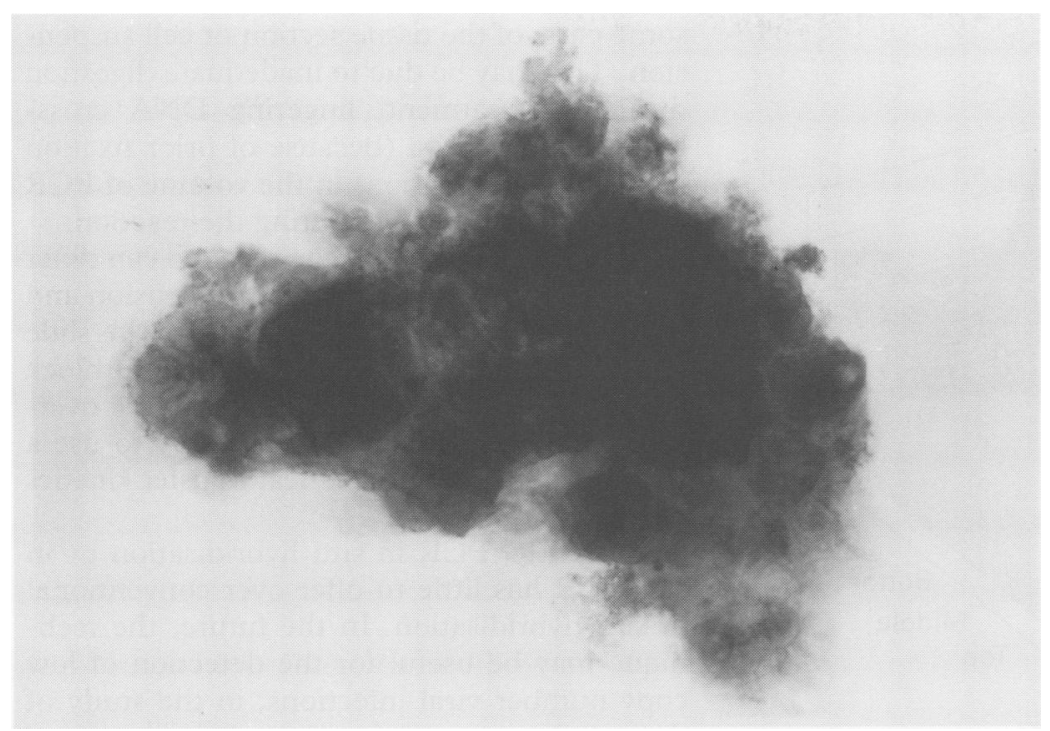

Figure 6 PCR in situ hybridisation of fixed CaSki cells showing diffuse amplification signal. Problems with localisation of signal are encountered when amplifying intermediate copy numbers of HPV16 in CaSki cells (200-300 copies).

Figure 7 Omitting Taq DNA polymerase yields no amplified product. Normal background copy number of HPV16 per CaSki cell is detected as in conventional DNA in situ hybridisation. (Lower power view than fig 6.)

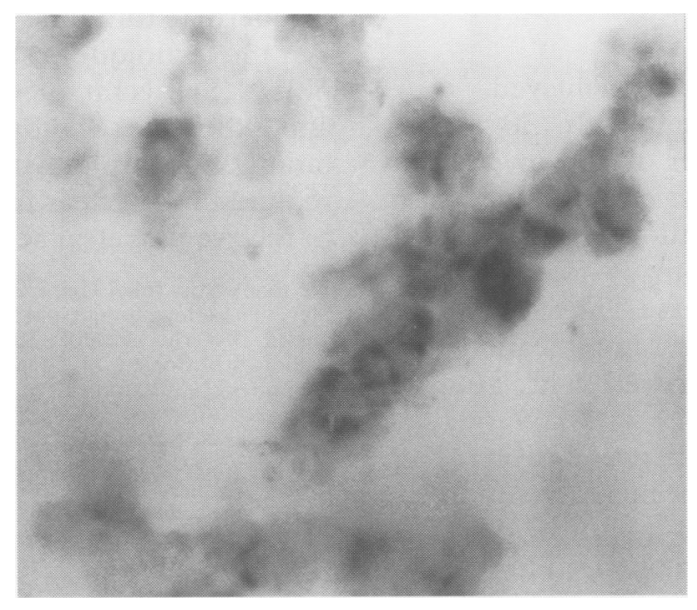

tions successful. There was no significant difference between the results obtained with biotin and digoxigenin as reporter molecules. "Diffuse" staining (fig 5) was also visible, with occasional cells showing dot positivity. The CaSki cell line contains 200 to 300 copies of HPV 16 per cell nucleus. Problems with localisation of signal in CaSki cells were encountered (fig 6). This was due to leakage of PCR amplified product from the site of amplification. Again, when Taq DNA polymerase was omitted from the amplifying solution, the normal copy number of HPV per CaSki cells was identifiable (fig 7). Cellular morphology preservation, however, was compromised.

In all cases $\beta$ globin gene was amplifiable from fixed cells using solution phase PCR. Again, HPV 16 primers yielded amplicons of appropriate size when used in solution phase PCR, but HPV 6, 11, 18, and 33 primers did not give amplification either with solution phase or PCR in situ hybridisation.

\section{Discussion}

In this study we examined the newly developed technique of PCR in situ hybridisation using fixed $\mathrm{SiHa}$ and $\mathrm{CaSki}$ cell lines as an experimental model for the detection of low and intermediate copy numbers of viral pathogens in fixed cells. We do not purport to have examined human structural genes. We were able successfully to amplify one to two copies of HPV 16 in fixed SiHa cells, which are not normally detectable with standard non-isotopic in situ hybridisation, except for complicated five-step sandwich techniques, ${ }^{9}$ as mentioned earlier. Discrete and diffuse signals were seen within the nucleoplasm of the fixed $\mathrm{SiHa}$ cells (figs 1, 2A, 2B, and 3). Fixation of cells for up to 24 hours appeared to yield material suitable for use with PCR in situ hybridisation. The results confirm the sensitivity of the technique for the detection of low copy number viral infection in infected cells. Fixed CaSki cells were also amplifiable after 12 to 24 hours of fixation. Problems with localisation of signal were commonly seen when using CaSki cells (fig 6). The reason for this is that the starting copy number of HPV in CaSki cells is much higher than in $\mathrm{SiHa}$ cells (200-300 copies compared with one to two copies). Such diffusion of product makes cytological and histological interpretation difficult. To overcome such diffusion problems, we advocate the use of paraformaldehyde and $100 \%$ alcohol dehydration after amplification. We have also clearly shown in this study that small amplicon PCR in situ hybridisation (120 base pairs) can be carried out successfully on fixed tissues using a single primer pair and the "hot start" PCR modification. In both experimental systems not all cells contained amplifiable product. This was primarily due to leakage of amplified product from truncated cells which have been cut by the microtome blade during sectioning of cells for the reaction-very much like a leaky bucket.

The success rate of the reaction ( $40 \%)$ was low, with failure and patchy amplification common. This is a poor success rate when compared with conventional in situ hybridisation. The choice of reporter molecule (biotin/digoxigenin) did not seem to affect the success rate of the reaction with equally sensitive results obtained with both reporter molecules.

Many centres have experienced consistent failure using PCR in situ hybridisation or in situ PCR. The following points should therefore be considered:

1 The cytoskeleton of the cell should be made rigid before PCR in situ hybridisation, to prevent cytoskeletal collapse during amplification. Cells or tissues should be fixed with formaldehyde. However, fixation of cells and tissues influences solution phase $\mathrm{PCR}^{10}$ and also seems to influence the results obtained with in situ PCR or PCR in situ hybridisation. ${ }^{11}$ The most important feature of formaldehyde fixation in relation to in situ PCR techniques is its ability to cross-link histone proteins that normally coat DNA, subsequently effecting the progression of Taq DNA polymerase along native DNA template.

2 In solution phase PCR attempts to override cross-linking using extensive digestion steps are made. ${ }^{12}$ However, in PCR in situ hybridisation extensive proteolytic digestion is not possible (in most cases 10 to 15 minutes, as in this study), so full dissociation of histone pro- 


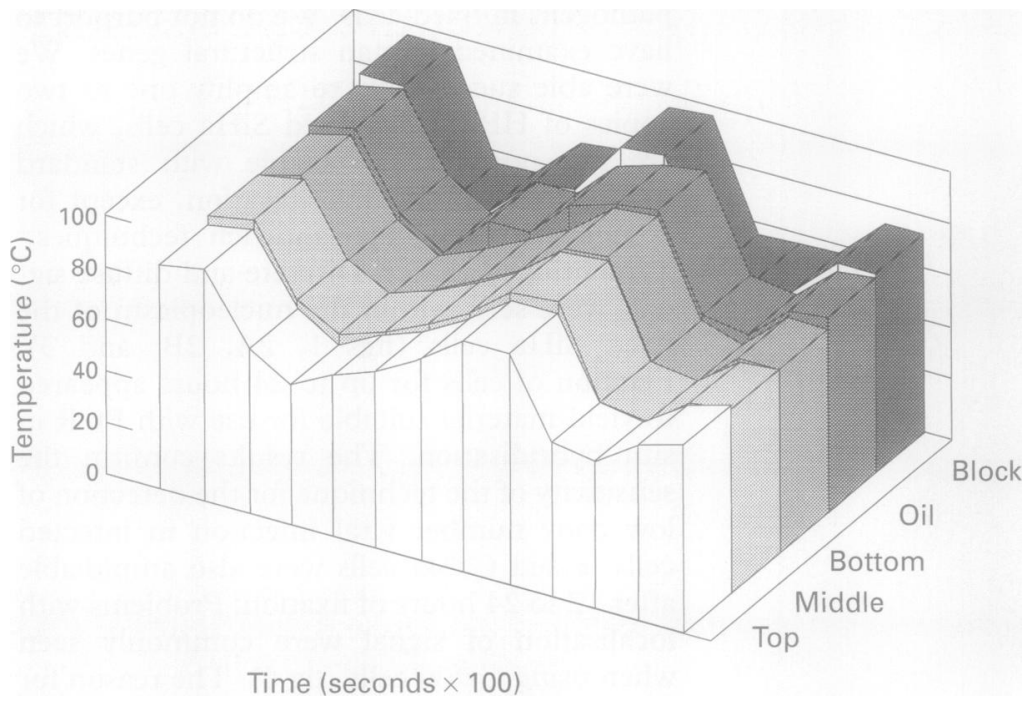

Figure 8 Typical thermal profile achieved during PCR in situ hybridisation amplification steps showing respective temperatures for the heating block, bottom, middle, and top of microscope slide and oil overlay interface. Note an important difference between the different temperatures recorded on the heating block and those achieved on the glass microscope slide during each of the phases of amplification.

teins from native DNA is not achieved. 3 Nuovo $^{2}$ estimates that with 30 cycles, amplification of the order of 200 to 300 -fold is achieved. Embretson et $a l,{ }^{13}$ however, have estimated that amplification levels achieved are of the order of 10 to 30 -fold, which is more likely to be the case. This practically represents almost linear amplification and reduced efficiency compared with solution phase PCR.

4 A dichotomy exists between using high concentrations of Taq, primers, etc., and the fact that the level of target nucleic acid is often much less than that routinely used in solution phase PCR. Some reagents seem to become sequestered during the amplification procedure itself, by any one of the following mechanisms: (a) adherence to glass of the slide; (b) reactive groups due to silanisation of slides; (c) reactive groups from fixation processes.

It is difficult to minimise such sequestration. However, Yap and $\mathrm{McGee}^{14}$ have reported that 0.1 to $1.0 \% \mathrm{BSA}$ is needed to achieve successful amplification of glass slide mounted tissue in "slide PCR" (a technique related to PCR in situ hybridisation, where amplification takes place on microscope slides and the amplified product is then analysed by standard electrophoresis)-BSA in this case possibly blocks sequestration of reagents during the reaction. In PCR in situ hybridisation, lower concentrations of Taq and primers can be used if slides are pretreated with $1 \% \mathrm{BSA}$ (unpublished observation, data not shown). 5 The success of in situ PCR depends on the amplified DNA product remaining localised. It is not clear how amplified DNA does not diffuse away from the site of amplification, but in our experience products of the order of 100 base pairs tend to diffuse quite readily. Postfixing the amplified product with $2 \%$ paraformaldehyde improves localisation. In the future immunofixation with lupus serum (containing anti-DNA antibodies) may be of use to maintain localisation of product.

6 Patchy amplification is also encountered, with amplification occurring preferentially in some parts of the tissue section or cell suspension. This may be due to inadequate digestion during pretreatment, lingering DNA crosslinking phenomena (because of prior fixation of cells), and variations in the volume of PCR reactants over the slide during the reaction.

7 The thermal profile of the reaction can differ at several sites on the slide/cell suspension and indeed varies from top to bottom of the slide and between the slide and the thermal block of the PCR machine (fig 8). This is the overwhelming reason why it is necessary to use a thermocouple to optimise heat transfer kinetics during amplification.

Currently, PCR in situ hybridisation or in situ PCR has little to offer over conventional in situ hybridisation. In the future, the technique may be useful for the detection of low copy number viral infections, in the study of the cellular expression of cellular oncogenes, growth factors, etc., and in the diagnosis of chromosomal translocations in certain tumour types (lymphomas, primitive neuroectodermal tumours, and Ewing's sarcoma). But the technique is still not reliable and PCR plus NISH techniques are inherently complex and expensive. Standardisation of instrumentation and simplification of the technique are required in the near future, if the technique is to receive universal acceptance.

We thank Miss Juliet Hamblin who typed the manuscript and Steve Toms for photographic assistance. This work was supSteve Toms for photographic assistance. This work was supported by the Health Research Board, Ireland, The
Pathological Society of Great Britain \& Ireland, and Apple Computers, Cork, Ireland.

1 Saiki RK, Scharf S, Falona F, Mullis KB, Horn GT, Erlich $\mathrm{HA}$, et al. Enzymatic amplification of globin genomic sequences and restriction site analysis for diagnosis of sickle cell anaemia. Science 1985;230:1350-4.

2 Nuovo GJ. PCR in-situ hybridisation/Protocols and applications. New York: Raven Press, 1992.

3 Haase AT, Retzel EF, Staskus KA. Amplification and detection of lentiviral DNA inside cells. Proc Natl Acad detection of lentiviral DNA

4 Nuovo GJ, Gallery F, MacConnell P, Becker P, Bloch W. An improved technique for the detection of DNA by insitu hybridisation after PCR amplification. Am $\mathcal{F}$ Pathol 1991;139:1239-44.

5 Nuovo GJ, MacConnell P, Forde A, Delvenne P. Detection of human papilloma virus DNA in formalin fixed tissues by in-situ hybridisation after amplification by PCR. Am F Pathol 1991;139:847-50.

6 Burns J, Graham AK, Frank C, Fleming KA, Evans MF, McGee J O'D. Detection of low copy human papilloma virus DNA and mRNA in routine paraffin sections of cervix by non-isotopic in-situ hybridisation. 7 Clin Pathol cervix by non-iso

7 Lewis FA, Griffiths S, Dunnicliff R, Wells M, Dudding N, Bird CC. Sensitive in-situ hybridisation technique using biotin-streptavidin polyalkaline phosphatase complex. $\mathcal{F}$ Clin Pathol 1987;40:163-6.

8 Herrington CS, Graham AK, McGee JO'D. Interphase cytogenetics using biotin and digoxigenin labelled probes III. Increased sensitivity and flexibility for detecting HPV in cervical biopsy specimens and cell lines. Clin Pathol 1991;44:33-8.

9 Herrington CS, de Angelis M, Evans MF, Troncone G, McGee J O'D. Detection of high risk human papilloma virus in routine cervical smears: strategy for screening. $\mathcal{F}$ virus in routine cervical sme

10 Ben Ezra J, Johnson DA, Rossi J, Cook N. Effect of fixation on the amplification of nucleic acids from paraffin tion on the amplification of nucleic acids from paraffin embedded material by the polymerase
Histochem Cytochem 1991;39:351-4.

11 Nuovo GJ, Gallery F, Horn R, MacConnell P, Bloch W. Importance of different variables for enhancing in-situ detection of PCR-amplified DNA. PCR Methods and Applications. 1993;2:305-12.

12 Jackson DP, Lewis FA, Taylor GR, Boylston AW, Quirke $P$. Tissue extraction of DNA and RNA and analysis by the polymerase chain reaction. $f$ Clin Pathol 1990;43: 499-503.

13 Embretson J, Zupancic M, Beneke J, Till M, Wolinsky S, Ribas $\mathrm{JL}$, et al. Analysis of human immunodeficiency virus-infected tissues by amplification and in situ single cell resolution. Proc Natl Acad Sci USA 1993 90:357-61.

14 Yap EPH, McGee J O'D. Slide PCR: DNA amplification from cell samples on microscopic glass slides. Nucl Acid Res 1991;19:4294. 